\title{
Langerhan's cell histiocytosis with oral manifestation in a 3-year-old child: a case
}

\section{report}

\section{Histiocitose de células de langerhans com manifestação oral em criança de 3 anos de idade: relato} de caso

Histiocitosis de células de langerhans con manifestación oral en un niño de 3 años: relato de un caso Universidade Federal do Paraná, Brazil E-mail: juliana.schussel24@gmail.com

Mara Albonei Dudeque Pianovski ORCID: https://orcid.org/0000-0003-0260-8506 Erasto Gaertner Cancer Center, Brazil Universidade Federal do Paraná, Brazil

E-mail: mpianovski@erastogaertner.com.br

Laurindo Moacir Sassi

\begin{abstract}
Langerhans cell histiocytosis (LCH) is a disorder that may affect the bones, skin, liver, lung, and hematopoietic and neuroendocrine systems. This condition may manifest as a single lesion, multiple lesions, or as a disseminated and potentially fatal disease. We aim to report a case of a 3-year-old child with LCH in the mandible, sharing with the readers the challenging process of this diagnosis. A three-year-old male patient with persistent swelling in the right submandibular region was referred to the Department of Pediatrics of the Erasto Gaertner Hospital for an evaluation. Initial physical exam revealed a diffuse flaccid swelling occupying the entire right mandibular ramus, from the angle to the preauricular region and CT scan showed an osteolytic lesion with erosion of the internal and external cortices of the mandible and an extension to soft tissues that displaced the masseter muscle. Immunohistochemical analysis confirmed the diagnosis of Langerhans cell histiocytosis through positive tests for CD1a, CD68, S-100, and Vimentin. The treatment proposed was a combination of Vinblastine $6 \mathrm{mg} / \mathrm{m} 3$ for 6 weeks and Prednisone 40mg for 4 weeks. The differential diagnosis included pathologies such as rhabdomyosarcoma, Ewing's sarcoma, and, less likely, osteosarcoma and central giant cell granuloma.
\end{abstract}

Keywords: Langerhans cell histiocytosis; Maxillofacial surgery; Oral pathology; Pediatric tumors.

\section{Resumo}

A histiocitose das células de Langerhans (HCL) é uma doença que pode afetar os ossos, a pele, o fígado, os pulmões, e os sistemas hematopoiético e neuroendócrino. Esta condição pode manifestar-se como uma única lesão, lesões múltiplas, ou como uma doença disseminada e potencialmente fatal. O nosso objetivo é relatar um caso de uma criança de 3 anos com HCL em mandíbula, partilhando com os leitores o processo desafiante deste diagnóstico. 
Paciente de três anos de idade, sexo masculino, com edema persistente na região submandibular à direita, foi encaminhado para o Serviço de Pediatria do Hospital Erasto Gaertner para uma avaliação. O exame físico inicial revelou edema flácido e difuso ocupando todo o ramo mandibular direito, desde o ângulo até à região pré-auricular. Tomografia computadorizada mostrou uma lesão osteolítica com erosão das corticais interna e externa da mandíbula e uma extensão aos tecidos moles com invasão do músculo masséter. A análise imunohistoquímica confirmou o diagnóstico de histiocitose de células de Langerhans através de testes positivos para CD1a, CD68, S-100, e Vimentina. O tratamento proposto foi uma combinação de Vimblastina $6 \mathrm{mg} / \mathrm{m} 3$ durante 6 semanas e Prednisona 40mg durante 4 semanas. O diagnóstico diferencial incluiu patologias como rabdomiossarcoma, sarcoma de Ewing, e, menos provavelmente, osteossarcoma e granuloma de células gigantes centrais.

Palavras-chave: Histiocitose de células de Langerhans; Cirurgia bucomaxilofacial; Patologia oral; Tumores pediátricos.

\section{Resumen}

La histiocitosis de células de Langerhans (HCL) es un trastorno que puede afectar a los huesos, la piel, el hígado, el pulmón y los sistemas hematopoyético y neuroendocrino. Esta enfermedad puede manifestarse como una lesión única, múltiples lesiones o como una enfermedad diseminada y potencialmente mortal. Nuestro objetivo es informar un caso de un niño de 3 años con HCL en la mandíbula, compartiendo con los lectores la dificultad de hacer el diagnóstico. Un paciente masculino de tres años de edad con inflamación persistente en la región submandibular derecha fue remitido al Departamento de Pediatría del Hospital Erasto Gaertner para su evaluación. El exame físico inicial reveló una hinchazón flácida y difusa, que ocupaba toda la rama mandibular derecha, desde el ángulo hasta la región preauricular. La TC mostró una lesión osteolítica con erosión de las corticales interna y externa de la mandíbula y una extensión a los tejidos blandos que desplazaba el músculo masetero. El análisis inmunohistoquímico confirmó el diagnóstico de histiocitosis de células de Langerhans mediante pruebas positivas para CD1a, CD68, S-100 y Vimentina. El tratamiento propuesto fue una combinación de Vinblastina $6 \mathrm{mg} / \mathrm{m} 3$ durante 6 semanas y Prednisona 40mg durante 4 semanas. El diagnóstico diferencial incluía patologías como el rabdomiosarcoma, el sarcoma de Ewing y, con menor probabilidad, el osteosarcoma y el granuloma central de células gigantes.

Palabras clave: Histiocitosis de células de Langerhans; Cirugía oral y maxilofacial; Patología oral; Tumores infantiles.

\section{Introduction}

Langerhans cell histiocytosis (LCH), the most common histiocytic disorder (Allen, Merad \& McClain, 2018) previously known as Histiocytosis X (the "X" denoting unknown etiology) (Abla, Rollins \& Ladisch, 2019), is a disorder characterized by abnormal proliferation of CD1a+/S-100/CD207+ Langerhans cells (Rodriguez-Galindo \& Allen, 2020; Tenorio et al., 2020), with a peak of incidence among children between 1 and 3 years of age (Postini et al., 2012), and is more prevalent in males than females (Guyot-Goubin et al., 2008). LCH may affect the bones, skin, liver, lung, and hematopoietic and neuroendocrine systems. The condition may manifest as a single lesion, multiple lesions, or as a disseminated and potentially fatal disease, with multi-organ involvement (Peters et al., 2017; Leung, Lam and Leong, 2019; Papo et al., 2019).

$\mathrm{LCH}$ in the oral cavity represent about $30 \%$ of cases of the disease, and the jaws are involved in $10 \%$ to $20 \%$ of cases. The mandible is one of the most commonly affected bones along with the skull, ribs and vertebrae (Peters et al., 2017). Oral lesions may be the first or only sign of manifestation the condition (Merglová et al., 2014), which increases the importance to early and assertive diagnosis. Detection of the disorder at an early stage results in fewer complications and sequelae to the patient.

The diagnosis of oral LCH lesions is generally challenging, mainly because the condition has a varied clinical presentation, and its characteristics may simulate infectious or periodontal diseases (Peters et al., 2017). Gingival lesions may cause bleeding and gingival retraction, commonly associated with tooth mobility or periodontal attachment loss. When mucosa is involved, LCH lesions have an irregular surface and may involve adjacent bone (Tenório, 2020), usually causing edema, pathological fractures, and severe tooth mobility. Osteolytic lesions with irregular edges and sclerotic margins are the most common signs identified in images (Merglová et al., 2014).

Being so, we aim to report a case of a 3-year-old child with $\mathrm{LCH}$ in the mandible, sharing with the readers the challenging process of this diagnosis. 


\section{Methodology}

This is a retrospective, descriptive, observational case study that demonstrates the challenge of diagnosing Langerhans' cell histiocytosis in a 3-year-old child. The study was approved by the Ethics Committee of Erasto Gaertner Cancer Center (n. 4.379.641) in respection to the Ethics Principle from Declaration of Helsinque. Epidemiological data, medical history, and photographic records were obtained from the medical records, after parental consent, following the precepts for publication without identification of the patient. In order to complement the paper, current literature searches were made using the MeSH Database through the keywords: Histiocytosis; Langerhans-Cell; Jaw Neoplasms; Mandible; Pediatrics. Based on the results found, a brief discussion on the subject was made.

\section{Case Report}

A three-year-old male patient with persistent swelling in the right submandibular region was referred to the Department of Pediatrics of the Erasto Gaertner Cancer Center (Curitiba, Paraná, Brazil) for an evaluation. The swelling had appeared 20 days before the appointment and was initially treated as parotitis, and subsequently as an odontogenic infection; neither treatment yielded results. According to the mother, the patient complained of pain only during palpation and did not have a fever or lost weight. The medical history revealed that the patient had been treated for iron deficiency anemia. No other diseases or medications were recorded. The initial physical exam revealed a diffuse flaccid swelling occupying the entire right mandibular ramus, from the angle to the preauricular region, shown in Figure 1.

Figure 1 - Facial initial aspect of the patient. On this photo, one may see a discrete diffuse from the angle to the preauricular region, with normal covering skin.



Source: Authors.

The skin surrounding the swelling appeared normal. The patient's primary dentition was complete, and all teeth were in good condition, without cavities, fillings, lesions, or fistula (Figure 2). 
Figure 2 - Initial intraoral aspect, showing teeth and mucosa in good condition, without cavities, fillings, lesions or fistula.

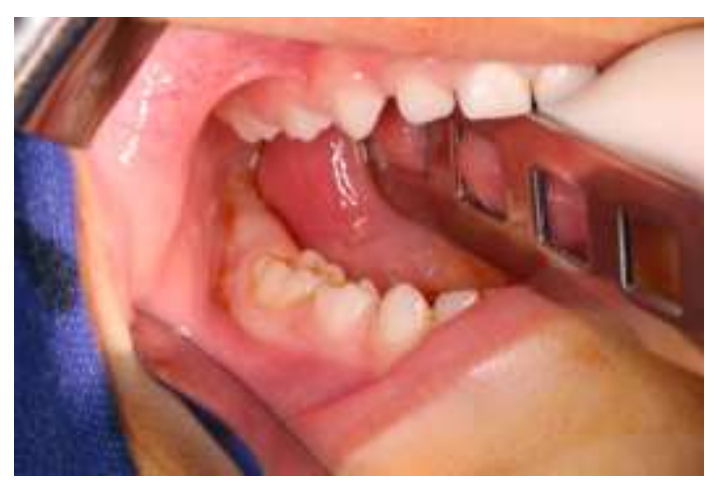

Source: Authors.

A CT scan was performed as soon as the child arrived and showed an osteolytic lesion with erosion of the internal and external cortices of the mandible and an extension to soft tissues that displaced the masseter muscle (Figure 3).

Figure 3 - Computed Tomography of the neck showing the initial aspect of the lesion, with erosion of the internal and external cortices of the mandible and extension to soft tissues. A) Axial section. B) Coronal section.
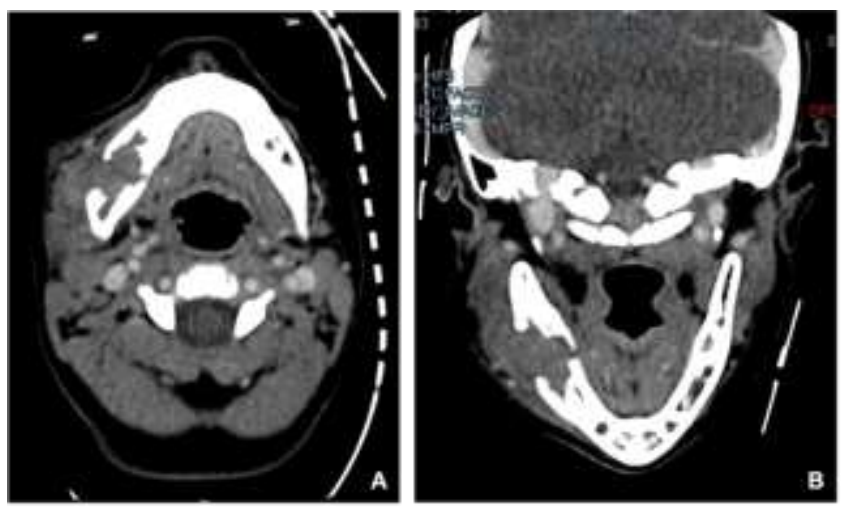

Source: Authors.

A periosteal reaction was also observed on both sides of the bone, suggesting an aggressive lesion. Three enlarged lymph nodes of up to $18 \mathrm{~mm}$ were observed, on the IB and IIA cervical levels, near the facial vessels on the right.

An incisional biopsy of the lesion was performed under general anesthesia. A whitish hard material was harvested from the mandibular body through intraoral access (Figure 4).

Figure 4 - Transoperative image showing the aspect of the pathological cavity.

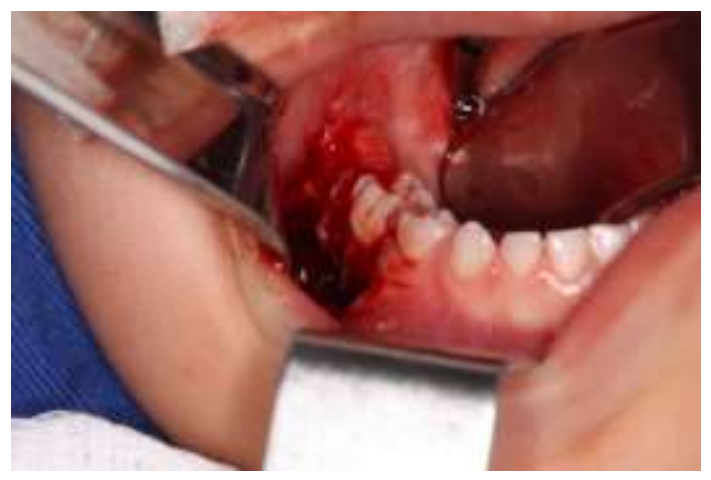

Source: Authors. 
The lesion did not seem to bleed, and the pathological cavity was wide but mostly empty. The anatomopathological result was that of a fusocellular neoplasm with discrete nuclear anaplasia, without mitosis or necrosis (Figure 5).

Figure 5 - Anatomopathological aspect of the first biopsy of the mandible, compatible with Fusocelular Neoplasia without necrosis and mitosis and with discrete nuclear anaplasia.

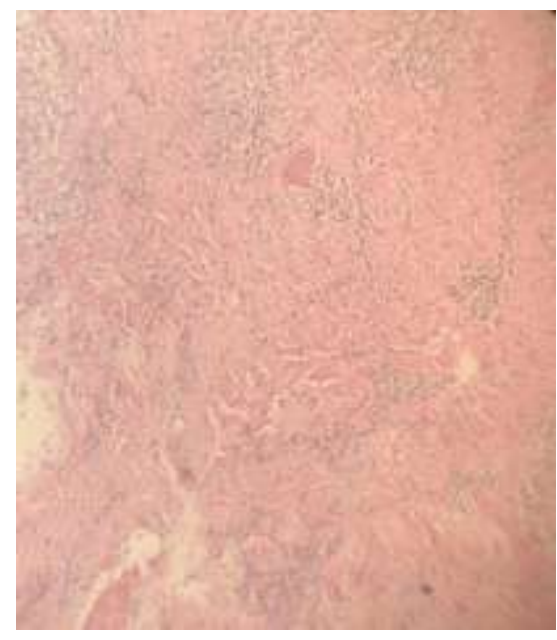

Source: Authors.

The immunohistochemical analysis was consistent with fusiform or polygonal cell proliferation, with giant cell permeation, suggesting a central giant cell lesion, as shown in Table 1.

Table 1. Immunohistochemical Markers - first biopsy.

\begin{tabular}{|ll|}
\hline Antibody & Result \\
CK AE1/AE3 & Negative \\
Vimentin & Positive in the cytoplasm of fusocellular/poligonal cells and giant cells \\
Desmin & Positive on the wall of blood vessels; Negative in the cells of interest \\
S-100 & Negative \\
CD68 & Positive in the cells of interest \\
Ki-67 & Positive between $10 \%-15 \%$ of neoplastic cell nuclei \\
\hline
\end{tabular}

Source: Authors.

Despite the histopathologic characteristics, questions remained about the real nature of the lesion. Therefore, a new biopsy was performed to obtain a definitive diagnosis. A larger specimen was removed along with the largest cervical lymph node (Figure 6). 
Figure 6 - Transoperative aspect of the lymph node biopsy, showing the soft tissue mass surrounding.

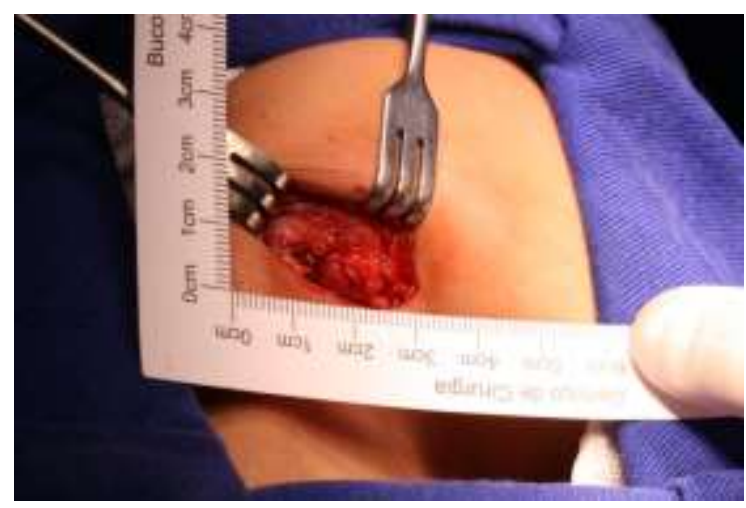

Source: Authors.

The anatomopathological analysis revealed an atypical proliferation of histiocytes and eosinophils associated with widespread fibrinogenic activity, bone neoformation, and osteoclast giant cells (Figure 7).

Figure 7 - Anatomopathological aspect of the second biopsy of the mandible, showing atypical proliferation of histiocytes and eosinophils associated with extensive fibrinogen activity, bone neoformation and osteoclast-like giant cells.

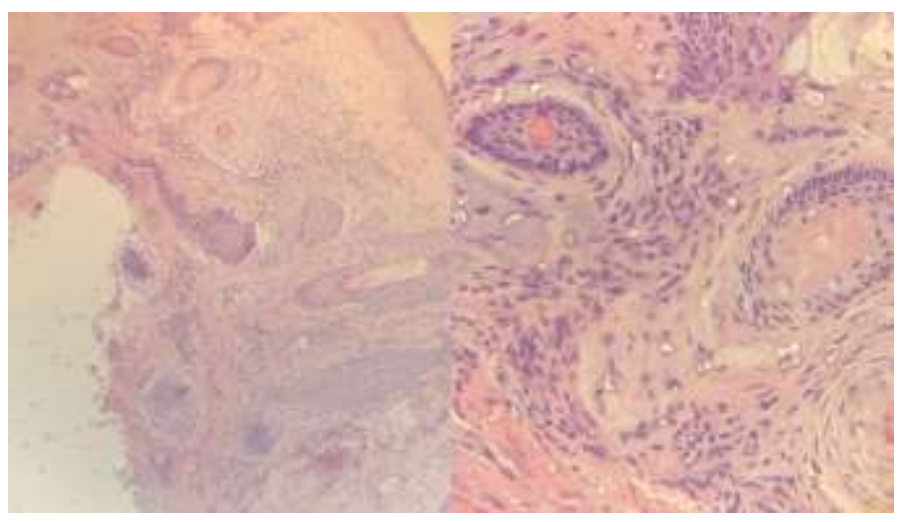

Source: Authors.

The lymph node analysis showed multifocal involvement by atypical and eosinophilic histiocyte aggregates (Figure 8). 
Figure 8 - Anatomopathological aspect of cervical lymph node, showing multifocal involvement by aggregates of atypical and eosinophilic histiocyte.

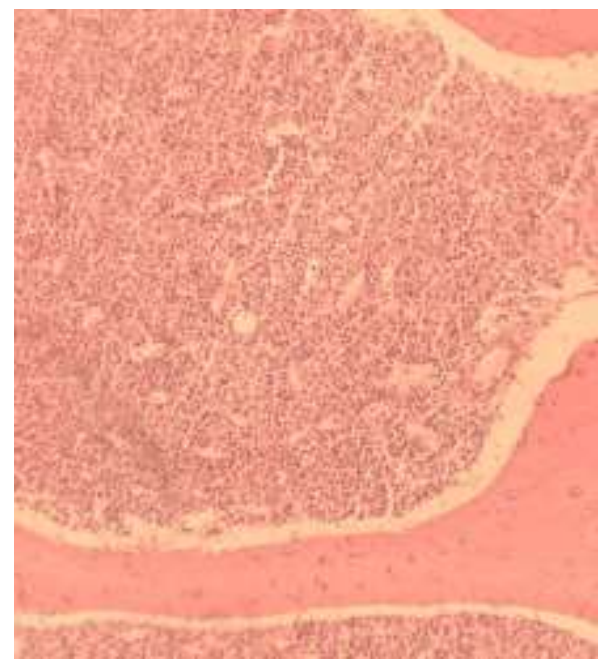

Source: Authors.

The immunohistochemical analysis confirmed the diagnosis of Langerhans cell histiocytosis through positive tests for CD1a, CD68, S-100, and Vimentin (Table 2).

Table 2. Immunohistochemical Markers - second biopsy.

\begin{tabular}{|ll|}
\hline Antibody & Result \\
Vimentin & Positive \\
CD1a & Positive \\
S-100 & Positive \\
CD68 & Positive \\
\hline
\end{tabular}

Source: Authors.

The patient was then referred to Pediatric Oncology for treatment. The treatment proposed was a combination of Vinblastine $6 \mathrm{mg} / \mathrm{m} 3$ for 6 weeks and Prednisone 40mg for 4 weeks. Surgical treatment was discarded once the lymph nodes compromised by the disease were identified. After one month of chemotherapy, a new CT showed a reduction in the dimensions of the lesion and no more evidence of mass involving soft tissues. No more lymph nodes were identified at IB and IIA levels. Currently, the patient remains in follow up, without use of medication. Last CT showed a nearly complete resolution of the mandibular lesion and no altered cervical lymph nodes.

\section{Discussion}

After the clinical and radiological evaluation of the patient — and considering the most prevalent tumors for patients at this age-, the differential diagnosis included agressive pathologies with osteolytic potential such as rhabdomyosarcoma (Davidson, Soldani \& North, 2006), Ewing's sarcoma (Heare, Hensley \& Dell' Orfano, 2009), Langerhans cell histiocytosis and, less likely, osteosarcoma (Kontio et al., 2019) and central giant cell granuloma (Wang et al., 2019; Silva et al., 2018).

LCH should be considered as a diagnostic hypothesis for pediatric patients due to the higher incidence of the disease in this population. Early diagnosis is essential for better prognosis. The diagnosis of LCH is clinicopathologic, based on typical findings and histologic/immunohistochemical examination of a biopsy of lesional tissue (Leung, Lam \& Leong, 2019; 
Weitzman \& Egeler, 2008; Donadieu, Chalard \& Jeziorski, 2012) If the histopathological report does not correspond to the clinical behavior of the disease, a new biopsy is essential to confirm the diagnosis and institute the most appropriate treatment. A new investigation procedure was decisive for the correct diagnosis and improvement of the patient's condition after treatment commenced.

Depending on the site of accumulation and proliferation of these cells, LCH may be classified into three different categories: unifocal, multifocal—which affect only a single organ, typically bone or skin — and multisystemic — which may cause organ dysfunction to high-risk organs such as lung, liver, or bone marrow. The bone is affected most frequently, and bony lesions occur most commonly in the skull, ribs, vertebrae and mandible. Jaws are involved in $10 \%$ to $20 \%$ of patients. The most frequently intraoral site is the posterior mandible (Peters et al., 2017), and according to the literature, lesions in the oral cavity are the first or only visible sign of LCH (Annibali et al., 2009; Merglová et al., 2014). These lesions may vary in characteristics, from ulcerative lesions of the oral mucosa and lesions that mimic periodontal disease (Annibali et al., 2009; Peters et al., 2017) to a considerable swelling, which is a differential diagnosis from malignant tumors such as Ewing's sarcoma (Oliveira et al., 2019).

Our patient presented a multifocal form, with the involvement of cervical lymph nodes, in addition to the mandibular bone lesion. The fast evolution of the lesion led to the diagnostic hypothesis of a malignant or aggressive benign lesion. The erosion of the mandible cortices and the extension to cervical lymph nodes revealed a multifocal disease.

The microscopic examination of the diseased tissue shows cells such as eosinophils, neutrophils, lymphocytes and histiocytes, in addition to Langerhans cells. This set of cells is traditionally described as Eosinophilic Granuloma. Abscess and tissue necrosis may also be present. During the analysis, it is evident the intense proliferation of histiocytes and positivity of CD1a, CD207 and S100 cells. In addition, Langerhans cells have an important pathognomonic sign, the so-called "Birbeck Granules”. In both of our cases, CD1 a cells were positive during immunohistochemical analysis (Claire et al., 2019).

The prognosis depends on the involvement of other organs, such as liver and bone marrow, and on the patient's response to initial therapy. The systemic treatment includes, as proposed in our case, the use of corticosteroids and cytostatic drugs (Krooks, Minkov \& Weatherall, 2018).

\section{Final Considerations}

The mandible is one of the most commonly affected bones in LHC along with the skull, ribs and vertebrae. Oral lesions may be the first/only sign of the condition, which increases the importance to early and assertive diagnosis.

\section{References}

Abla, O., Rollins, B., \& Ladisch, S. (2019). Langerhans cell histiocytosis: progress and controversies. British Journal of Haematology. $187(5), 559-562$.

Allen, C. E., Merad, M., \& McClain, K. L. (2018). Langerhans-Cell Histiocytosis. New England Journal of Medicine, 379(9), 856-868.

Annibali, S., Cristalli, M., Solidani, M., Ciavarella, D., La Monaca, G., Suriano, M. \& Lo Russo, L. (2009). Langerhans cell histiocytosis: oral/periodontal involvement in adult patients. Oral Diseases, 15(8), 596-601.

Claire, K., Bunney, R., Ashack, K. A., Bain, M., Braniecki, M., \& Tsoukas, M. M. (2020). Langerhans Cell Histiocytosis: A greater imitator. Clin in Dermatology, 38 (2), 223-234.

Davidson, L. E., Soldani, F. A., \& North, S. (2006). Blackwell Publishing Ltd Rhabdomyosarcoma of the mandible in a 6-year-old boy. International Journal of Paediatric Dentistry, 16(4), 302-306.

Donadieu, J., Chalard, F., \& Jeziorski, E. (2012). Medical management of Langerhans cell histiocytosis from diagnosis to treatment. Expert Opin Pharmacother, 13(1), 1309-1322.

Guyot-Goubin, A., Donadieu, J., Barkaoui, M., Bellec, S., Thomas, C., \& Clavel, J. (2008). Descriptive epidemiology of childhood Langerhans Cell Histiocytosis in France, 2000-2004. Pediatr Blood Cancer, 51(1), 71-75. 
Research, Society and Development, v. 10, n. 5, e40310515136, 2021

(CC BY 4.0) | ISSN 2525-3409 | DOI: http://dx.doi.org/10.33448/rsd-v10i5.15136

Heare, T., Hensley, M. A., \& Dell' Orfano, S. (2009). Bone tumors: osteosarcoma and Ewing's sarcoma. Current opinion in pediatrics, 21(3), 365-372.

Kontio, R., Hagstrom, J., Lindholm, P., Bohling, T., Sampo, M., Mesimaki, K., Saarilahti, K., Koivunen, P., \& Makitie, A. A. (2019). Craniomaxillofacial osteosarcoma - The role of surgical margins. Journal of Cranio-Maxillo-Facial Surgery, 47(6), 922-925.

Krooks, J., Minkov, M., \& Weatherall, A. G. (2018). Langerhans cell histiocytosis in children: History, classification pathobiology, clinical manifestations and prognosis. J Am Acad Dermatol, 78(6), 1035-1044.

Leung, A. K. C., Lam, J. M., \& Leong, K. F. (2019). Childhood Langerhans cell histiocytosis: a disease with many faces. World Journal of Pediatrics, 15(6), 536-545.

Merglová, V., Hrusak, D., Boudová, L., Mukensnabl, P., Valentová, E., \& Hosticka, L. (2014). Langerhans cell histiocytosis in childhood - Review, symptoms in the oral cavity, differential diagnosis and report of two cases. J Cranio-Maxillofac Surg, 42(2), 93-100.

Oliveira, S. V., Fernandes, L. G., Soares Jr, L. A. V., Moraes, M. F., Almeida, M. T. A., Pinto Jr, D. S., \& Alves, F. A. (2019). Mandible Ewing Sarcoma in a child: Clinical, radiographic and diagnosis considerations. Oral Oncology, 98, 171-173.

Papo, M., Cohen-Aubart, F., Trefond, L., Bauvois, A., Amoura, Z., Emile, J.F., \& Haroche, J. (2019). Systemic Histiocytosis (Langerhans Cell Histiocytosis, Erdheim-Chester Disease, Destombes-Rosai-Dorfman Disease): from Oncogenic Mutations to Inflammatory Disorders. Current Oncology Reports, $21(7), 62$.

Peters, S. M., Pastagia, J., Yoon, A. J., \& Philipone, E. M. (2017). Langerhans cell histiocytosis mimicking periapical pathology in a 39-year-old man. J Endod, 43(11), 1909-1914.

Postini, A. M., Prever, A. B., Pagamo, M., Rivetti, E., Berger, M., Asaftei, S. D., Barat, V., Andreacchio, A., \& Fagioli, F. (2012). Langerhans cell histiocytosis: 40 year's experience. In J Pediatric Hema-tolol Oncol, 34(5), 353-8.

Rodriguez-Galindo, C., \& Allen, C. E. (2020). Langerhans Cell histiocytosis. Blood, 135(16), 1319-1331.

Silva, R. N. F., Tino, M. T., Costa, N. L., Batista, A, C., Mendonça, E. F., \& Ribeiro-Rotta, R. F. (2018). Central Giant Cell Lesion Mimicking Osteosarcoma. Oral Surgery, Oral Medicine, Oral Pathology, Oral Radiology., 126(3): e100

Tenorio, J. R., Esteves, C. V., Heguedusch, D., Sousa, S. C. O. M., \& Lemos-Júnior, C. A. (2020). Oral and cutaneous manifestations of langerhans cell histiocytosis: report of two cases. J Oral Maxillofac Surge Med Pathol, 32(1), 72-75.

Wang, Y., Le, A., El Demellawy, D., Shago, M., Odell, M., \& Johnson-Obaseki, S. (2019). An aggressive central giant cell granuloma in a pediatric patient: case report and review of literature. J of Otolaryngol: Head \& Neck Surg, 48(1), 32.

Weitzman, S. \& Egeler, R. M. (2008). Langerhans cell histiocytosis: update for the pediatrician. Curr Opin Pediatr. 20(1), $23-29$. 